\title{
Synchronization of Worm
}

\section{Fanglian He}

Carnegie Institution at Stanford

[Abstract] Attaining a large synchronized population of worms is desirable for use in some assays in order to eliminate variation in results due to age differences. Two ways to get synchronized worms include egg preparation via bleaching and egg lay. The former in general yields more progeny than the latter, however, egg lay can generate a better synchronized population than egg preparation.

\section{Materials and Reagents}

1. General chemicals (Sigma-Aldrich)

2. Regular bleach (Clorox)

3. M9 buffer

4. Worm lysis solution

\section{Equipment}

1. Votex (Scientific Industries)

2. Vacuum pump (Welch)

3. $15 \mathrm{ml}$ conical tube

4. $60 \times 15 \mathrm{~mm}$ petri dish (VWR)

\section{Procedure}

A. Egg preparation via bleaching

1. Chunk starved worms onto a seeded (with bacterial food, $E$ coli OP50-1) NGM plate (60 $\mathrm{x}$ $15 \mathrm{~mm}$ ). Allow the worms to grow for about 2 days at $25^{\circ} \mathrm{C}$.

2. Once you have plenty of eggs/adults, pour $6 \mathrm{ml}$ of $\mathrm{M9}$ buffer onto the plate and gently swirl it to dislodge the worms.

3. Transfer $5 \mathrm{ml}$ worms to a $15 \mathrm{ml}$ conical tube.

4. Add $5 \mathrm{ml}$ of $2 x$ worm lysis solution to the tube.

5. Vortex the tube at max speed for approximately 4 min or until you see very few intact adult worms (usually bleach no longer than 6 min, otherwise the eggs will be killed). 
6. Centrifuge at $\sim 1,000 \times g$ for $1 \mathrm{~min}$.

7. Carefully decant the supernatant without disturbing the worm pellet.

8. Wash twice with $10 \mathrm{ml}$ of $\mathrm{M9}$ buffer (spin at $\sim 1,000 \times \mathrm{g}$ for $1 \mathrm{~min}$ )

9. Add $7 \mathrm{ml}$ of $\mathrm{M9}$ buffer to resuspend the egg pellet.

10. Let eggs shake overnight at $20^{\circ} \mathrm{C}$ to hatch. Since there is no food the larvae should be halted at the L1 stage.

11. Next day, let the tube sit on the bench for 10 - 15 min and starved L1 worms can precipitate by gravity.

12. Remove most of supernatant and distribute the liquid onto seeded plates or into liquid culture.

Note: This protocol is also used to remove bacterial and yeast contamination from a worm strain.

B. Egg lay

Gravid worms have a maximal egg-laying rate of 7 eggs $/ \mathrm{h}$ at $20^{\circ} \mathrm{C}$.

13. Pick 10-15 gravid worms/plate.

14. Incubate at desired temperature $\left(15,20\right.$, or $\left.25^{\circ} \mathrm{C}\right)$ for desired time $(2-6 \mathrm{~h})$.

15. Remove adults by suction off the plate or picking.

16. Grow until progeny are at appropriate stage.

\section{References}

1. Sulston, J. \& Hodgkin, J. (1988) Methods. In: The Nematode Caenorhabditis elegans. (Ed.): W.B. Wood. Cold Spring Harbor Laboratory Press: New York, 587-606.

2. Shapira, M. and Tan, M. W. (2008). Genetic analysis of Caenorhabditis elegans innate immunity. Methods Mol Biol 415: 429-442. 